\title{
Law of forfeiture faced with radical reform - An overview of the Landlord and Tenant (Termination of Tenancies) Bill
}

Received (in revised form): 5 December 2006

\section{Guy Walton}

works as an In-House Real Estate Lawyer for John Lewis Plc and Waitrose Ltd and has been responsible for dealing with all aspects of their respective retail trading, development and investment portfolios since joining John Lewis in the early 2006. Guy's previous experience includes working for seven years in real estate private practice in the city.

\begin{abstract}
At the end of October 2006, the Law Commission presented a report to the government including a new Bill entitled 'The Landlord and Tenant (Termination of Tenancies) Bill'. The Bill proposes radical reform to the existing law of forfeiture in relation to leases, which has for a long time been heavily criticised on the grounds of its perceived unfairness to tenants. The clear objective of the new regime is to ensure that the consequences of any tenant breach under any lease are proportionate and appropriate principally for Human Rights Act 1998 purposes.In particular, the Bill proposes:
\end{abstract}

- A future regime whereby no tenancy can be forfeited until the court makes a corresponding 'Termination Order'.

- A widening of the powers of the court to award alternative 'remedies' to 'Termination Orders' such as 'Remedial Orders', 'Orders for Sale' and 'Transfer Orders'.

- To abolish all physical forfeiture rights of re-entry that landlords currently enjoy in favour of a new 'Summary Termination Procedure' intended as expedited means for landlords to regain possession of premises. Subject to some proposed exceptions, this procedure will apply in circumstances where tenants have no realistic prospect of defending landlord

Guy Walton

Property Lawyer Legal Services Department John Lewis Partnership Partnership House Carlisle Place London $\mathrm{SW}_{1} \mathrm{P}_{1 \mathrm{BX}}$, UK Tel: + 442075925016 Fax: + 442075926566 E-mail: Guy_Walton@johnlewis.co.uk possession claims.

\section{Keywords:}

landlord, tenant, lease, termination, forfeiture

Journal of Retail and Leisure Property (2007) 6, 101-107.

doi:10.1057/palgrave.rlp.5100050 


\section{INTRODUCTION}

On 31 October 2006, the Law Commission produced a report for the government outlining a new statutory scheme for the termination of tenancies including the above draft Bill. The government is now in the process of considering the report, and it is anticipated that the Bill will be presented to the Parliament for enactment in the coming months.

It is clear that one of the principal aims of the proposed reform is to address the perceived failings of the current forfeiture regime and, in particular to have greater regard to the human rights of tenants pursuant to the Human Rights Act 1998. This coupled with the general aim of the Law Commission to make law more accessible through the enactment of statute means that the new Bill stands a good chance of being passed through Parliament as soon as possible.

\section{CURRENT LAW OF FORFEITURE}

It is considered that the current law of forfeiture is antiquated. In the words of the Law Commission, it is 'complex, lacks coherence and can lead to injustice to the detriment of tenants'. Criticisms are as follows:-

1. There are presently unnecessary distinctions between the treatment of the different types of recognised tenant breaches and, principally, the use of Section 146 of the Law of Property Act 1925. This section currently applies to most breaches of covenant save for breaches for nonpayment of rent and requires a landlord to serve notice on a tenant specifying the breach and requiring the tenant to remedy that breach (if indeed it is capable of remedy).

2. Timing issues. Legally, when a landlord commences forfeiture proceedings, a 'constructive re-entry' takes place at the moment of service of those proceedings on the tenant and not on the date the court makes a corresponding order for possession. It is then incumbent on the tenant to bring a claim for 'relief' to retrospectively revive the relevant tenancy. Together with physical re-entry by a landlord (which terminates a tenancy at the moment of such re-entry), terminations in this way constitute the fundamental human rights inequalities, which the new scheme is seeking to address.

3. A landlord can only forfeit a lease for breach of a tenant's covenant where the right to forfeit is expressly contractually reserved by the relevant lease. This is an obvious detriment to all landlords.

4. Once a landlord has established grounds to forfeit a lease (and before it has re-entered), currently, it must not do anything to acknowledge that its tenant continues to be its tenant; for example, by making rent demand. If it does so, the landlord is deemed to have waived the relevant breach and will consequently lose the right to forfeit on that ground.

The new Bill addresses the above by way of the following:-

1. In future, no distinction will be made between breaches for nonpayment of rent and remediable and nonremediable breaches. 
Instead, all breaches will be treated as 'tenant defaults' by virtue of which a landlord will be entitled to bring a claim to terminate a tenancy before the end of its contractual term.

2. The tenancy in respect of which a tenant default has taken place will continue to exist until the court makes a 'termination order', notwithstanding the existence of the tenant default or the service of any termination proceedings by the landlord.

3. All landlords' physical re-entry rights will be abolished. In future, only the court will be able to order the termination of any tenancy.

4. Leases will no longer need to expressly incorporate forfeiture rights for the new scheme to apply.

5. The doctrine of waiver will be abolished and in future, all landlords will be entitled to take termination action in respect of tenant defaults, which have already been remedied. This will protect landlords against those tenants who commit persistent breaches of covenant.

6. The law of forfeiture as it presently stands will be completely abolished in favour of the new scheme.

\section{TENANT DEFAULT}

The principal feature of the new scheme is the concept of 'tenant default'. A landlord will only be entitled to invoke the scheme on the occurrence of any such default. A tenant default is effectively the breach of a covenant or condition of the relevant tenancy by the tenant.

Where a tenant default occurs, the landlord is entitled to serve a default notice on the tenant detailing the relevant breach, any required remedial action and a compliance date.

The following points should also be noted:

1. Although waiver will be abolished by the new scheme, a landlord will only be able to validly serve a default notice where it serves the same within six months of it becoming aware of the tenant default in question, or within six months of any continuing tenant default.

2. Although it will no longer be necessary to expressly include forfeiture provisions in 'post-commencement' tenancy agreements (ie tenancy agreements that post-date the enactment of the new scheme), it will not be possible to take any action in respect of any tenant default until a landlord has served 'an explanatory statement' fully detailing the potential forfeiture consequences of any tenant default to the relevant tenant. It is intended that such notices will be in a prescribed form.

3. Although it will not be a strict requirement for a landlord to serve the explanatory statement at the outset of a tenancy for the new scheme to be effective (as is the case by way of analogy in respect of contracting out of security of tenure pursuant to the Landlord and Tenant Act 1954), it is anticipated that, in practice, this is the practice most landlords will adopt.

4. In addition to the abolition of the current forfeiture regime, it will be open to landlords and tenants to 'contract out' of the new scheme in respect of 'post-commencement' tenancies. This means that it will be 
possible for landlords and tenants to expressly contractually provide that breaches of specific covenants and/or conditions by tenants will not constitute tenant defaults, which would otherwise entitle landlords to serve default notices. Such covenants and conditions will therefore constitute 'excepted covenants' for the purposes of the new scheme.

5. When it comes into force, the new scheme will apply to all tenancies and will also apply retrospectively to 'pre-commencement tenancies' (ie those tenancies completed subject to the current law of forfeiture). It will, however, not apply to 'pre-commencement tenancies' that do not contain express forfeiture rights in favour of the landlord. This is because the automatic application of the new scheme to such tenancies would constitute unjust enhancement of landlord's rights and consequently, would be contrary to the human rights of the relevant tenants.

6. To ensure that all 'qualifying interest holders' (ie those deriving any interest from a tenancy) will be protected, it will be necessary for landlords to make such qualifying interest holders aware of all tenant default notices and all subsequent remedies sought. This will be achieved under the new scheme by a requirement for landlords to give tenant default notices to every relevant qualifying interest holder, who the landlord will be deemed to have knowledge of. Qualifying interest holders will include all sub-tenants, mortgagees and holders of option and pre-emption rights affecting the subject property.

\section{COURT ACTION}

Where any tenant does not observe the requirements of any tenant default notice, the court will have a wide discretion under the new scheme to make such remedial orders as it considers to be appropriate and proportionate in the circumstances. By way of a brief summary, the orders that the court shall be entitled to make include:-

1. Termination order: This is likely to be awarded where there are no qualifying interest holders and will constitute an order to terminate a tenancy on a specified date.

2. Remedial order: This will be an order preserving the tenancy, but requiring the tenant to remedy the relevant tenant default by a specified date. In default of such rectification, the landlord will be entitled to re-apply to the court for a termination order.

3. Order for sale: It is expected that this order will apply to tenancies of high capital values (including long residential and long commercial tenancies granted for initial premiums, but at subsequent ground rents). The proceeds of sale arising from an order for sale will then be distributed in a specific prescribed order (with one of the beneficiaries being the landlord in respect of sums owed to it by the tenant).

4. Transfer order: As a separate remedy, where a tenancy contractually permits assignment, any qualifying interest holder will be entitled to 
call for a transfer of the existing tenancy to it. Alternatively, any qualifying interest holder will be able to apply for a new tenancy order to be on such terms as the court considers appropriate in the circumstances.

5. In addition, it should be noted that the court will not limit itself to considering remedies available under the new scheme and will also consider all other usual remedies available; such as damages, injunctions and specific performance.

\section{EXCEPTIONS TO THE AVAILABILITY OF REMEDIES}

Certain exceptions will apply. For example, a tenant defaulting under its repairing covenant of a lease of greater than seven years with more than three years left to run will be able to benefit from the protection afforded to it under the Leasehold Property (Repairs) Act 1938 in respect of that default. It will therefore not be possible for a landlord to serve a tenant default notice in respect of any such breach in the same way that correspondingly, the landlord cannot forfeit for such breach under the current law.

Also, where the 1938 Act applies, a landlord will not be entitled to use the summary termination procedure (summarised below).

\section{SUMMARY TERMINATION PROCEDURE}

This is an alternative to a tenant making a termination claim pursuant to a tenant default and may lead to the termination of a tenancy without the court making a termination order.

The procedure is designed to constitute an expedited means of termination without the delay and costs associated with applying to the court for a termination order. This procedure, however, will still enable a landlord to recover possession of the subject premises and is designed to replace the current law of physical re-entry as a method of terminating a tenancy.

A landlord will not be entitled simultaneously to apply for a termination order and a summary termination, and will have to choose at the outset which route it wishes to take. There may, however, be circumstances where a landlord initially opts for the summary termination procedure and later chooses termination order proceedings where the summary proceedings prove unsuccessful.

The principal difference between the current law of re-entry and the new summary procedure is that the new procedure will not immediately bring a tenancy to an end. Instead, the invoking of the summary procedure will only constitute the beginning of a process whereby a tenancy may be terminated.

In addition to the Leasehold Property (Repairs) Act exemption mentioned above, the summary termination procedure will not be available in any of the following cases:

1. Cases involving residential tenancies or any tenancies having an unexpired term of more than 25 years. 
2. Where the parties to a lease expressly agree to exclude the summary termination procedure from the relevant lease.

3. Where the breach in question is an 'excluded covenant' as summarised above.

4. In relation to 'pre-commencement tenancies' where there is no express corresponding forfeiture provision in that tenancy, which would enable the landlord to forfeit the tenancy by peaceful re-entry for breach of covenant.

The summary process is designed to be used where there is no realistic prospect of a tenant or any qualifying interest holder setting aside a landlord's application for a termination order and could also be used for example where it is evident that premises have been abandoned.

A brief synopsis of the summary procedure is as follows:-

1. The process is invoked by a landlord serving a summary termination notice on the tenant. The notice may only be served in respect of a tenant default that occurs within six months of the landlord having knowledge of such default. The landlord will also have to serve the notice on all qualifying interest holders.

2. The notice will be in prescribed form and will need to specify the tenant default and the date upon which the tenancy will terminate. This date will be one month after the notice service date.

3. During the said one-month period, the tenant (or any qualifying interest holder) will be able to apply to the court for an order to discharge the notice. If the tenant is successful, the tenancy will continue and the landlord will no longer be able to continue with the summary termination application. As an alternative application however, a landlord would then be entitled to apply to the court for a termination order.

4. After the expiry of the one-month period, where there has been no successful setting aside of the notice, the tenancy will terminate and the landlord will be entitled to recover possession. This is, however not necessarily the end of the story. After the tenancy has terminated in this way, the tenant (or any qualifying interest holder) will still have the opportunity to apply for relief for a period of six months from and including the termination date.

5. The court will have the discretion to respond to any such tenant relief application by making any order it considers to be appropriate and proportionate including the grant of a new tenancy to the applicant or the payment of compensation. Under no circumstances, however, will the court be able to order the retrospective revival of the terminated tenancy.

\section{CONCLUSION}

The clear and stated objective of the new scheme is to ensure that the consequences for breach of any tenant covenant should be both proportionate and appropriate in view of the requirements of the Human 
Rights Act 1998. It is evident that there is a rising groundswell of opinion that the present law of forfeiture does not achieve such proportionality.

In this way, in future when the new scheme is in force, no tenancy will be capable of determination without a corresponding court order to that effect.

The new scheme is designed to facilitate early exchanges of information between all interested parties and to bring them (especially qualifying interest holders) around the negotiating table as early as possible to promote negotiation, settlement and compromise otherwise than by means of litigation and determination via the courts.

As the new Bill is currently only in draft, it remains to be seen whether all of the Law Commission's recommendations will be adopted. That said, however, it would appear to be very likely that the law of forfeiture is on the verge of a major reform. 